\title{
DEVELOPING RELATIONSHIP OF TEACHERS AND STUDENTS THROUGH SNAP DIARY AS A CHILDREN'S FRIENDLY SCHOOL SUPPORT IN ELEMENTARY SCHOOL
}

\author{
Wulan Tri Puji Utami
}

IKIP PGRI Wates

wulantripujiutami@gmail.com

Article History

accepted 09/07/2018

approved 01/08/2018

published 17/09/2018

\section{Keywords}

teacher, student, snap diary, child-friendly schools

\begin{abstract}
Education really aims to humanize humans. When a childborn into the world, he is equipped with various potential that must be actualized. The process of actualization is done deliberately called the educational process. The teacher plays an important role in the processeducation primarily in shaping a child's ability to shape skillsin the form of cognitive, affective and psychomotor. Teachers are also influential to make improvements to a healthy learning environment, conducive and comfortable for students. Complete school facilities are certainly not a guarantee for the protection of children's rights because violence in primary school-aged children is still common in schools. Implementation of child-friendly school program is done to reduce the problem to the students according to rights in convention of child. One of the main pillars of child-friendly school is the availability of a healthy, safe and protective environment. Schools also serve to protect children's rights so that children feel safe from violence, abuse and exploitation. While it is easy to understand that a nonviolent environment is a prerequisite of productive learning, it is certainly more difficult to take precautions. Improving the relationship of teachers and students to be one strategic action to understand the needs of each student. Effective communication relationship can be done through snap diary program. Every student has right and freedom to talk about the events that he has experienced. Through a snap diary, students can express the events they experienced not only through writing but also through pictures. Teacherwhich has a large number of classes will be easier to analyze the problems of students through snap dairy.
\end{abstract}

Social, Humanities, and Education Studies (SHEs): Conference Series https://jurnal.uns.ac.id/shes
p-ISSN 2620-9284

e-ISSN 2620-9292 


\section{PENDAHULUAN}

Pendidikan adalah sintesa tertinggi dalam kehidupan. Bangsa yang maju dan beradab mempunyai masyarakat dengan kecerdasan intelektual serta memiliki karakter yang baik. Hal tersebut sesuai dengan tujuan dari pendidikan di Indonesia seperti yang tertuang dalam UU Sistem Pendidikan Nasional No. 20 tahun 2003. Pendidikan Nasional bertujuan untuk mengembangkan potensi peserta didik agar menjadi manusia yang beriman dan bertakwa kepada Tuhan Yang Maha Esa, berakhlak mulia, sehat, berilmu, cakap, kreatif, mandiri, dan menjadi warga negara yang demokratis serta bertanggung jawab. Pendidikan adalah kunci penting dalam perkembangan kualitas sumber daya manusia. Ari Ginanjar (2008:8) menyatakan bahwa menurut Ki Hajar Dewantara pendidikan adalah tuntunan di dalam hidup tumbuhnya anak-anak, yaitu menuntun segala kodrat yang ada pada anak-anak itu agar sebagai manusia dan sebagai anggota masyarakat dapat mencapai keselamatan dan kebahagiaan yang setinggi-tingginya. Dapat disimpulkan bahwa pendidikan mempunyai dua tujuan utama yaitu, peserta didik menjadi cerdas dan baik.

Dengan ungkapan yang hampir sama Amstrong (2006:39) mengatakan bahwa tujuan pendidikan adalah untuk mendukung, mendorong, dan memfasilitasi perkembangan peserta didik sebagai manusia yang utuh (a whole human being). Beberapa pendapat di atas menyatakan bahwa pendidikan sesungguhnya bertujuan untuk memanusiakan manusia. Ketika seorang anak lahir ke dunia, ia dibekali dengan berbagai potensi yang harus dimunculkan atau diaktualisasikan. Proses aktualisasi yang dilakukan secara sengaja disebut proses pendidikan.

Pendidikan dasar tersebut diawali dari sekolah dasar sampai dengan sekolah menengah pertama. Sekolah dasar merupakan tempat ditanamkannya konsep-konsep sederhana sebagai bekal agar peserta didik mampu melanjutkan belajarnya pada jenjang yang lebih tinggi dan sebagai tempat membangun ranah kognitif, afektif dan psikomotor peserta didik. Proses tumbuh kembang di Sekolah dasar mempunyai peran penting karena peserta didik mengabiskan waktu 7-9 jam di sekolah. Maka hubungan guru dan peserta didik harus tetap efektif karena guur adalah orang tua peserta didik di sekolah.

Guru berperan untuk memberikan bimbingan dan menyelesaikan permasalahan yang terjadi pada peserta didik. Akan tetapi, di era globalisasi saat ini sering terjadi kekerasan pada peserta didik di sekolah. Fakta makin merebaknya berbagai tindak kekerasan, bulliying, dan rasisme menunjukkan lingkungan sekolah yang seharusnya menjadi lingkungan positif bagi peserta didik menunjukkan perlunya perbaikan pada hubungan baik guru dengan peserta didik, guru dengan orang tua wali, guru dengan guru dan juga hubungan antar peserta didik. Berbagai fenomena kekerasan dan tindakan yang disebabkan kehilangan empati juga telah terjadi. Komisi Perlindungan Anak Indonesia (KPAI) mencatat tahun 2012 terjadi peningkatan kasus kekerasan terhadap anak di sekolah hingga lebih dari 10\%. Wakil Komisi Perlindungan Anak Indonesia (KPAl) Apong Herlina mengatakan kekerasan terhadap anak di lingkungan sekolah terjadi dalam berbagai jenis baik itu dilakukan oleh guru maupun antar peserta didik. Catatan ini didasarkan pada hasil survey KPAI di 9 propinsi terhadap lebih dari 1000 orang peserta didik. Baik dari tingkat Sekolah Dasar/MI, SMP/MTs, maupun SMA/MA (viva.co.id 2012)

Selain itu, kasus kekerasan yang terjadi selama kurun waktu tahun 2013 Komisi Nasional Perlindungan Anak (Komnas PA) melaporkan sebanyak 3.023 kasus pelanggaran hak anak terjadi di Indonesia sebanyak $58 \%$ jadi korban kejahatan seksual. Dilihat dari klasifikasi usia, dari 3.023 kasus tersebut, sebanyak $45 \%$ terjadi pada anak berusia 13 hingga 17 tahun, korban berusia 6 hingga 12 tahun sebanyak $26 \%$, dan usia 0 hingga 5 tahun sebanyak $29 \%$ (liputan 6, 2013). Berdasarkan penelitian tersebut didapat juga informasi bahwa $65 \%$ guru dan orang tua terlambat 
mengetahui kekerasan yang telah terjadi pada peserta didik karena hubungan guru dan orang tua hanya bersinergi pada persoalan akademis peserta didik.

Berdasarkan hasil riset dari KPAI menunjukkan bahwa sekolah belum bisa menjadi tempat yang ramah bagi anak (peserta didik). Maka Sekolah Ramah Anak sebagai program nasional oleh Kementerian Pemberdayaan Perempuan dan Perlindungan Anak Republik Indonesia berfungsi melindungi hak anak agar anak merasa aman dari kekerasan, penganiayaan dan eksploitasi. Tentu guru sangat berperan penting dalam mengidentifikasi lingkungan positif dan negatif bagi peserta didik apalagi guru SD berperan penuh sebagai konselor di sekolah. Hubungan guru, orang tua dan peserta didik menjadi kunci untuk mewujudkan sekolah ramah anak. Maka perlu peningkatkan kualitas hubungan antar guru dan peserta didik. Realita saat ini Guru hanya berperan untuk meningkatkan hasil belajar atau prestasi peserta didik, guru kurang memahami perannya sebagai orang tua bagi peserta didik di Sekolah.

Sosok orang tua memiliki tanggung jawab untuk mendidik, mengasuh dan membimbing anak-anaknya untuk mencapai tahapan tertentu yang menghantarkan anak untuk siap dalam kehidupan bermasyarakat maka orang tua adalah sosok pertama yang mengetahui jika ada permalasahan dengan anak. Begitupun di sekolah, Guru wajib mengetahui karakter, kelebihan dan kelemahan peserta didik. Guru kelas menjadi sosok orang tua yang paham akan kesulitan atau permasalahan dalam diri peserta didik. Maka perlu media komunikasi yang efektif karena guru kelas setidaknya memiliki minimal 20 peserta didik tentu hanya memiliki waktu yang terbatas untuk berkomunikasi secara langsung. Setidaknya dibutuhkan media yang efektif, salah satunya dengan Snap diary antara guru dan peserta didik. Dalam jurnal ini akan dipaparkan analisis Snap diary untuk mengembangkan hubungan antara guru dan peserta didik.

\section{Sekolah Ramah Anak}

\section{PEMBAHASAN}

Sekolah adalah rumah bagi anak, rumah yang memberikan kenyamanan, kehangatan dan menjadi tempat yang dirindukan oleh anak. Setidaknya itu adalah gambaran sederhana tentang sekolah ramah anak sebagai bagian program pendidikan ramah anak. Penerapan Sekolah Ramah Anak telah dipaparkan dalam Permen No 8 tahun 2014, sebagai wujud keseriusan pemerintah dalam menjunjung hak dan kesetaraan anak. Sekolah Ramah Anak adalah sekolah yang secara sadar berupaya menjamin dan memenuhi hak-hak anak dalam setiap aspek kehidupan secara terencana dan bertanggung jawab. Prinsip utama adalah non diskriminasi kepentingan, hak hidup serta penghargaan terhadap anak. Sebagaimana dalam bunyi pasal 4 UU No.23 Tahun 2002 tentang perlindungan anak, menyebutkan bahwa anak mempunyai hak untuk dapat hidup tumbuh, berkembang, dan berpartisipasi secara wajar sesuai harkat dan martabat kemanusiaan, serta mendapatkan perlindungan dari kekerasan dan diskriminasi. Salah satunya adalah berpartisipasi yang dijabarkan sebagai hak untuk berpendapat dan didengarkan suaranya. Maka perlu dibangun hubungan yang berkualitas antara guru dan peserta didik, guru bukan hanya bertindak sebagai tokoh yang pasti selalu benar akan tetapi pendapat peserta didik perlu diperhatikan karena setiap perserta didik itu unik dan mempunya kelebihannya masing-masing.

\section{Prinsip pelaksanaan Sekolah Ramah Anak}

Ada dua karakteristik utama Sekolah Ramah Anak adalah It is a child-seeking school yaitu Sekolah Ramah Anak membantu peserta didik untuk mengetahui hak dan kewajibanya sebagai anak. Selain itu Sekolah Ramahan Anaka proaktif untuk mencari semua anak yang termarginalisasi dari pendidikan, menghargai keberagaman dan memastikan kesetaraan untuk peserta didik. Sehingga bisa disimpulkan bahawa Sekolah Ramah Anak itu adalah sekolah yang aman, sehat dan memberikan perlindungan. Karakteristik yang kedua It is a child-centred school. Sekolah Ramah 
Anak menjadikan kebutuhan setiap peserta didik akan mendapat pelayanan terbaik. Kesejahteraan, kesehatan dan gizi peserta didik akan selalu dimonitor. Metode kreatif menjadi tonggak utama dalam pembelajaran di sekolah. Sekolah Ramah Anak tidak hanya peduli pada kejadian yang terjadi pada peserta didik di Sekolah akan tetapi juga selalu aktif peduli dengan hubungan peserta didik dengan orang tua dan lingkungannya.(UNICEF, 2012)

Sehingga bisa didefinisikan bahhwa Sekolah Ramah Anak adalah sekolah yang secara sadar berupaya menjamin dan memenuhi hak-hak anak dalam setiap aspek kehidupan secara terencana dan bertanggung jawab. Prinsip utama adalah non diskriminasi kepentingan, hak hidup serta penghargaan terhadap anak

Sekolah ramah anak harus memenuhi kualitas pada 5 aspek, hal ini dipaparka dalam "Assessing Child Friendly Schools: A Guide for Programme Managers in East Asia and the Pacific. UNICEF EAPRO publication (UNICEF, 2006). Prinsip tersebut adalah:

1. Kualitas peserta didik yang sehat didukung dengan gizi yang baik.

Peserta didik juga mendapat dukungan dari keluarga untuk siap belajar di sekolah

2. Kualitas kurikulum dan bahan pembelajaran yang mendukung perkembangan literasi, pengetahuan, aritmatika, sikap dan life skill.

3. Kualitas proses belajar dan mengajar bersifat student center berbasis keterampilan dan teknologi.

Kualitas lingkungan belajar yang mendukung perkembangan peserta didik.

4. Fasilitas sekolah yang memenuhi standar berupa ruang kelas, sanitasi bersih, sirkulasi udara menjadi kebutuhan peserta didik. Kebijakan di sekolah yang menampung pendapat dari peserta didik dan orang tua wali.

5. Kualitas hasil belajar terukur pada aspek kognitif, afektif dan psikomotor.

Assesment yang sesuai baik di kelas dan di jenjang nasional.

Sedangkan menurut Bashori (2010: 97) sebuah kawasan bisa dimasukan dalam kategori ramah anak apabila memiliki ciri-ciri sebagai berikut:

1. Anak terlibat dalam pengambilan keputusan tentang masa depan diri, keluarga, dan lingkungannya.

Setiap peserta didik mempunyai kemampuan yang unik. Guru harus yakin pada kemampuan anak. Keyakinan dan kepercayaan ini akan membuat sikapnya memberikan keleluasaan dan menempatkan anak sebagai subjek dan center pembelajaran. Tentu kepercayaan dan kesempatan yang diberikan oleh guru membuat peserta didik akan terbantu untuk mewujudkan keinginannya untuk bereksplorasi dan mengembangkan potensinya.x

2. Memberikan kemudahan untuk layanan dasar pendidikan, kesehatan dan layanan tumbuh kembang.

Pengembangan kawasan ramah anak menunjukkan bawah faktor kesehatan yang sangat penting untuk keberlangsungan hidup manusia. Maka seorang anak itu harus mendapatkan suatu pelayanan pendidikan dan kesehatan dengan mudah karena anak merupakan generasi emas untuk melanjutkan pembangunan bangsa dan negara.

3. Adanya ruang terbuka untuk anak dapat berkumpul, bermain, dan berkreasi dengan sejawatnya dengan aman serta nyaman.

Keamanan dan kenyaman merupakan hal yang harus diperhatikan oleh pihak sekolah.

4. Adanya aturan yang melindungi anak dari bentuk kekerasan dan eksploitasi.

Pihak sekolah harus benar-benar memperhatikan dan melindungi anak dari segala bentuk kekerasan dengan membuat peraturan serta kebijakan yang 
mendukung perlindungan anak karena kasus kekerasan saat ini banyak peserta didik menjadi korban kekerasan di sekolah.

5. Menghilangkan diskriminasi dalam hal apapun terkait suku, ras, agama, dan golongan (SARA).

Saat ini Indonesia sangat rentan oleh isu SARA baik dalam dunia politik ataupun pendidikan. Tentu saja hal ini sangat memprihatinkan karena selayaknya harus bangga terhadap keberagaman Indonesia, diskriminasi terhadap suatu golongan masih sangat terasa di lingkungan masyarakt. Indonesia terdiri dari berbagai macam suku, ras, agama, dan berbagai golongan. Oleh karena itu, perlu adanya penanaman sikap saling menghormati dan menghargai satu sama lain yang tentunya dimulai dari seorang anak-anak. Hal ini dapat dilakukan dalam kegiatan pembelajaran dan kehidupan sehari-hari.

Dari pemaparan tersebut dapat disimpulkan bahwa suatu sekolah dapat dikatakan ramah anak apabila dengan melihat kondisi lingkungan belajar yang aman, nyaman, dan penuh kasih sayang antara anak dengan guru, orang tua, maupun sesama teman sebayanya sangat berpengaruh dalam membentuk karakter seorang anak dan meningkatkan kualitas pendidikan di Indonesia.xx

Guru-guru perlu menempatkan dirinya sebagai orang tua peserta didik saat di sekolah, yang peduli, memperhatikan dan mencarikan solusi yang dihadapi setiap peserta didik. Jika selama ini komunikasi yang dijalin terbatas pembicaraan hal-hal akademis, guru bisa mulai membuka pembicaraan nonakademis dengan peserta didiknya. Dengan demikian, peserta didik merasa diperhatikan. Mesti diupayakan bahwa saat berada di sekolahpun, peserta didik tetap merasa ada di rumah kedua.

\section{Hubungan guru dan peserta didik melalui Snap Diary}

Pasal 1 ayat (1) UU No. 14 Tahun 2005 tentang Guru dan Dosen, pengertian guru adalah pendidik profesional dengan tugas utama mendidik, mengajar, membimbing, mengarahkan, melatih, menilai, dan mengevaluasi peserta didik pada pendidikan anak usia dini jalur pendidikan formal, pendidikan dasar, dan pendidikan menengah. Menurut Grambs \& Mc Clare (2003: 141): "Teacher are those persons who consciously direct the experiences and behavior of an individual so that education takes places." Guru adalah mereka yang secara sadar mengarahkan pengalaman dan tingkah laku dari seorang individu hingga dapat terjadi pendidikan. Dari beberapa pendapat di atas, maka dapat disimpulkan bahwa guru adalah seorang pendidik profesional dengan tugas utama mendidik peserta didik pada pendidikan anak usia dini jalur pendidikan formal, pendidikan dasar, dan pendidikan menengah.

Guru harus menjadi panutan dan dihormati oleh peserta didik, untuk itu guru harus mampu memberikan dan menunjukan contoh perilaku yang baik dalam setiap kesempatan, baik di sekolah maupun di luar. Misalnya, saat menerangkan sesuatu permasalahan atau menjelaskan materi tidak menggunakan atau memberikan katakata yang kurang baik untuk seusia anak SD. Menunjukan sikap disiplin, misalnya guru harus membiasakan datang ke sekolah dan masuk kelas tepat waktu. Agar semua siswanya termotivasi untuk datang dan masuk kelas lebih awal sehingga tidak akan ada yang terlambat masuk kelas. Pada jurnal Discipline, learning skills and academic achievement menemukan korelasi antar disiplin, kemampuan belajar dan prestasi akademik. Temuan dari penelitian kuantitatif yang dilakukan di antara 143 siswa kelas lima di Israel dan Amerika Serikat menunjukkan korelasi positif yang signifikan antara empat keterampilan disiplin dan prestasi akademik dan guru mempunyai peran penting dalam meningkatkan keterampilan disiplin tersebut dengan kontrak disiplin (Pasternak, 2013:1). Sedangkan menurut penelitian di Kenya, Departemen Pendidikan (MOE) bekerja sama dengan para pemangku kepentingan untuk memastikan bahwa peserta didik menyadari korelasi antara disiplin dan kinerja di KCSE (Kenya Certificate of Secondary Education) sehingga tugas inti pendidik adalah untuk menanamkan sikap, 
keterampilan, dan pengetahuan tentang disiplin pada peserta didik (Josephine, et al, 2013:1). Sebagai pendidik, guru tidak hanya bertugas memberi dan menyampaikan materi mata pelajaran saja, melainkan harus dapat membimbing, mengarahkan dan memberi teladan yang baik untuk peserta didiknya sehingga dapat membantu menumbuhkan dan mengembangkan perilaku yang postif bagi peserta didik.

Seorang pendidik hanya dapat memberikan kepada anak didiknya apa-apa yang dipunyainya (Purwanto, 2014: 88). Pendapat itu menjelaskan bahwa jika seorang pendidik atau guru itu sendiri sering berbuat sesuatu yang tidak baik atau salah terhadap peserta didiknya maka akan sia-sia semua apa yang telah ia berikan kepada peserta didik itu. Snap diary terdiri dari dua kata yaitu Snap dan Diary. Diary adalah buku harian. Catatan harian adalah catatan kejadian yang kita alami sehari-hari yang ditulis oleh seseorang tentang segala masalah atau segala persoalan sehari-hari. Catatan harian ditulis secara harian atau tidak secara harian, catatan harian (diary) merupakan salah satu jenis tulisan yang menarik bagi kita, baik untuk tujuan menulis segala masalah yang muncul di pikiran (Komadi, 2011: 206). Sedangkan menurut Wahono (2010 : 15) menulis buku harian merupakan kumpulan peristiwa penting dalam hidup seseorang. Setiap orang memiliki sejarah hidup yang berbeda-beda, seseorang pasti melakukan sesuatu atau mengalami sesuatu setiap harinya. Terkadang orang merasa gembira, sedih, marah, kecewa, dan simpati terhadap seseorang semua itu dituliskannya ke dalam catatan harian. Berdasarkan pemaparan di atas dapat disimpulkan bahwa catatan harian adalah karangan yang berisi catatan pribadi.

Komadi (2011: 207) membagi manfaat catatan harian menjadi enam, diantaranya adalah 1) dengan menulis berlatih mengungkapkan pendapat dan perasaan secara spontan dan sistematis. 2) dengan menulis berfikir obyektif dan berfikir bening. 3) dengan menulis bisa mengurangi benang kusut persoalan yang sebelumnya rumit. 4) dengan menulis bisa mengurangi ketegangan dan stres. 5) dengan menulis bisa mengabadikan ide-ide, kenangan, atau peristiwa yang dianggap penting dan berkesan. 6) dengan menulis bisa tumbuh lebih dewasa dan bijak. Fungsi catatan harian adalah sebagai kenangan masa-masa yang pernah kita alami. Bisa juga sebagai momento atau sejarah kehidupan. Seiring dengan perubahan zaman yang terlalu cepat sehingga perubahan tersebut membuat individu semakin stres entah dengan kariernya atau keluarganya, catatan harian atau buku haria pun berubah fungsi dari sekedar menyimpan kenangan menjadi sebuah media untuk mencurahkan perasaan seseorang atas masalah yang dihadapinya.

Seseorang dapat menggunakan diary untuk menuliskan catatan, peristiwa ataupun hal yang dirasakan saat itu. Manfaat menulis buku harian adalah menjadi sumber inspirasi, mengasah rasa bahasa, membuat memori atau ingatan bertambah kuat, membuat indra bertambah tajam, membuat mengerti banyak hal, membuat lebih kreatif, melatih kecerdasan emosi dalam mengabadikan peristiwa penting. Sedangkan kata Snap diambil dari Snapchat adalah aplikasi pesan foto yang dikembangkan Evan Spiegel, Bobby Murphy, dan Reggie Brown saat masih kuliah di Universitas Stanford. Dengan aplikasi ini, pengguna dapat mengambil foto, merekam video, menambahkan teks dan lukisan, dan mengirimkannya ke daftar penerima yang ditentukan pengguna.( https://id.wikipedia.org/wiki/Snapchat). Jadi Snap diary adalah catatan harian, peristiwa atau masalah sehari-sehari peserta didik dengan bentuk tulisan dan kolom gambar, sehingga peserta didik bisa menggunakan tulisan ataupun gambar peristiwa, kegiatan pada Snap diary.

Kolom gambar bisa berupa gambar yang dibuat peserta didik, foto cetak, gambar yang digunitng dari media majalah atau koran. Jadi snap diary akan menampung cerita, peristiwa, gagasan dengan metode kreativitas sehingga akan lebih menarik dan sesuai dengan usia perkembangan peserta didik SD. Selain itu, berdasarkan penelitian yang dilakukan oleh Septina Rinawati (2015) tentang pemanfaatan buku harian (diary) 
juga digunakan untuk mengembangkan kecerdasan linguistik. Penelitian tersebut menghasilkan nilai koefisien determinasi sebesar 0,008 yang menunjukkan kebiasaan menulis buku harian berpengaruh positif terhadap kecerdasan linguistik sebesar $0,8 \%$, sedangkan 99,2\% sisanya dipengaruhi oleh variabel lain. Maka diharapkan seiring meningkatnya kecerdasan linguistik akan meningkatkan keterampilan berkomunikasi antara guru dan peserta didik. Misal, peserta didik menuliskan hal yang berhubungan dengan kekerasan maka guru bisa tanggap dengan keadaaan tersebut.

Perkembangan peserta didik yang berada pada sekolah dasar berada pada rentangan usia dini. Pada usia tersebut seluruh aspek perkembangan kecerdasan seperti $I Q, E Q$, dan $S Q$ tumbuh dan berkembang sangat luar biasa. Pada umumnya tingkat perkembangan masih melihat segala sesuatu sebagai satu keutuhan (holistik) serta mampu memahami hubungan antara konsep secara sederhana. Proses pola pikir masih bergantung kepada obyek-obyek konkret dan pengalaman yang dialami secara langsung sehingga akan lebih mudah untuk menulis catatan harian.

Masa usia sekolah dasar sebagai masa kanak-kanak akhir yang berlangsung dari usia enam tahun hingga kira-kira usia sebelas tahun atau dua belas tahun. karakteristik utama siswa sekolah dasar adalah menampilkan perbedaan-perbedaan individual dalam segi kognitif dan bidangnya, diantaranya, perbedaan dalam intelegensi, kemampuan dalam kognitif dan bahasa, perkembangan kepribadian dan perkembangan fisik anak. Jean Peaget (Slavin, 2010: 45), anak usia Sekolah Dasar termasuk pada tahap tahap kongkrit operasional (7-11 tahun). Kemampuan berpikir anak pada tahap ini masih dalam bentuk konkret, belum mampu berpikir abstrak. Aktivitas pembiasan yang melibatkan peserta didik dalam pengalaman langsung sangat efektif dibandingkan penjelasan guru dalam bentuk verbal (kata-kata) sehingga diharapkan melalu Snap diary terjadi proses hubungan yang positif antara guru dan peserta didik.

Sedangkan menurut Tim Pengembang MKDP Kurikulum dan Pembelajaran (2017: 28), ada usia anak Sekolah Dasar, anak-anak lebih mudah diarahkan, diberi tugas yang harus diselesaikan, dan cenderung mudah untuk belajar berbagai kebiasaan. Maka melalui kebiasan menulis Snap Diary diharapkan peserta didik dapat menunjukkan segala sesuatu tentang dirinya baik kebiasaan sehari-hari, kegemaran, kekecewaan terhadap seseorang, ketakutan akan suatu hal dan lain sebagainya. Jadi, melalui Snap Diary akan memudahkan guru untuk memahami karakteristik setiap peserta didiknya karena setiap anak itu unik dan hebat.

Aktivitas menulis Snap Diary bisa dilakukan untuk anak kelas 1-6 SD karena menulis diary membutuhkan pembiasaan. Perbedaan diary dan snap diary adalah terletak pada koolom gambar yang disediakan. Selain itu Snap diary tidak wajib diisi setiap hari, karena kemungkinan peserta didik akan kebingungan karena tidak biasa menulis buku harian. Maka guru bisa memulai untuk membuat kontrak dengan peserta didik untuk mengisi Snap diary dalam waktu seminggu tiga kali lalu secara bertahap ditingkatkan frekuensinya menjadi setiap hari. Guru bisa memberikan reward untuk peserta didik yang menulis dengan jujur.

Guru juga harus menyediakan waktu untuk mengisi Snap diary sesuai dnegan kesepakatan dengan peserta didik, misal 15 menit setelah istirahat. Snap diary harus ditinggal di kelas dengan pengawasan oleh guru kelas. Peserta didik tidak diperkenankan untuk membawa snap diary ke rumah karena untuk mencegah intervensi dari orang tua wali. Akan tetapi, guru tetap bisa membangun komunikasi dengan orang tua jika ada catatan penting atau krusial dalam Snap diary. Setiap hari guru harus meluangkan untuk membaca Snap diary peserta didik. Lalu setiap akhir semester guru menganalisis permasalahan dan karakteristik yang muncul pada setiap peserta didik jika ada permasalahan guru kelas harus menghubungi kepala sekolah. Akan tetapi jika permasalahannya berat maka guru bisa melakukan diskusi dengan psikologi atau Komisi Perlindungan anak. 


\section{SIMPULAN}

Salah satu pilar utama dari Sekolah Ramah Anak adalah tersedianya lingkungan yang sehat, aman dan protektif. Sekolah juga berfungsi melindungi hak anak agar anak merasa aman dari kekerasan, penganiayaan dan eksploitasi. Walaupun mudah untuk memahami bahwa lingkungan tanpa kekerasan adalah prasyarat dari pembelajaran yang produktif, tentu lebih sulit untuk melakukan tindakan pencegahan. Meningkatkan hubungan guru dan peserta didik menjadi salah satu tidakan strategis untuk memahami kebutuhan setiap peserta didik.

Guru berperan penting dalam proses pendidikan terutama dalam membentuk kemampuan seorang anak untuk membentuk keterampilan berupa kognitif, afektif dan psikomotor. Guru juga berpengaruh untuk melakukan perbaikan lingkungan belajar yang sehat, kondusif dan nyaman untuk peserta didik. Fasilitas sekolah yang lengkap tentu tidak menjadi jaminan bagi perlindungan hak-hak anak karena kekerasan pada anak usia sekolah dasar masih sering terjadi di sekolah. Penerapan program Sekolah ramah Anak dilakukan untuk mengurangi permasalahan pada peserta didik sesuai hakhak dalam konvensi anak.

Setiap peserta didik mempunyai hak dan kebebasan untuk bercerita tentang peristiwa yang telah dialaminya. Melalui snap diary, peserta didik bisa mengekspresikan peristiwa yang dialaminya tidak hanya melalui tulisan tapi juga melalui gambar. Guru yang mempunyai jumlah kelas besar akan lebih mudah untuk menganalisis permasalahan peserta didik melalui snap dairy. Jadi hubungan komunikasi efektif dapat dilakukan melalui program snap diary

\section{DAFTAR PUSTAKA}

Amstrong, Thomas. (2006). The best school: How human development research should inform educational practice. Virginia: Association for Supervision and Curriculum development.

Ary Ginandjar Agustian. (2008). Pembentukan habit menerapkan nilai-nilai religious, social dan akademik. Proceeding. Seminar dan Lokakarya Nasional Restrukturisasi Pendidikan Karakter. Universitas Negeri Yogyakarta. Yogyakarta . 29 Juli 2008.

Bashori Muchsin, dkk. 2010. Pendidikan Islam Humanistik: Alternatif Pendidikan Pembebasan Anak. Bandung: Refika Aditama.

Grambs, J. D., \& Mc Clare, C. M. 2003. Who is Teacher?. Quezon City: Claretian Publish.

http://nasional.news.viva.co.id/news/read/655240-kpai-kekerasan-terhadap-anakmeningkat-tajam.

http://news.liputan6.com/read/2191106/survei-icrw-84-anak-indonesia-alamikekerasan-di-sekolah.

Josephine W. G., Michael T. K., Bernard G. N. (2013).Correlation Between Students' Discipline and Performance In The kenya Certificate of Secondary Education. International Journal of Education and Research, 1(8), 1-2.

Komadi. (2011). Manfaat Menulis Buku Harian. Sukoharjo: PT. Insan Mulia.

Pasternak, R. (2013). Discipline, learning skills, and academic achievement. School of behavioral Sciences, COMAS, The college of Management Academic Studies

Division (COMAS), Rishon Lezion. Accces Intenational Journal. 1(1), 1-2.

Peraturan Menteri Negara Pemberdayaan Perempuan dan Perlindungan Anak No. 8 Tahun 2014 Tentang Kebijakan Sekolah Ramah Anak.

Purwanto. (2014). Evaluasi hasil belajar. Yogyakarta: Pustaka Belajar.

Robert. E Slavin. 2010. Cooperative Learning Teori, Riset dan Praktik. Bandung:Nusa Media 
Septina Rinawati. (2015). Pengaruh Kebiasaan Menulis Buku Harian terhadap kecerdasan Linguistik pada siswa kelas IV Sd Muhammadiyah 3 Surakarta tahun Pelajaran 2014/2015. Skripsi, tidak diterbitkan, Surakarta: Universitas Muhammadiyah Surakarta.

Undang-undang Nomor 14 Tahun 2005 tentang Guru dan Dosen Undang-undang Nomor 14 Tahun 2005 tentang Guru dan Dosen Undang-undang Nomor 20 Tahun 2003 tentang Sistem Pendidikan Nasional

UNICEF. (2006). "Assessing Child Friendly Schools: A Guide for Programme Managers in East Asia and the Pacific. UNICEF EAPRO publication

UNICEF. (2012) Child friendly Schools. Retrieved from http://www.unicef.org/lifeskills/ index 7260.html

Wahono. (2010). Menanamkan keterampilan menulis dengan cara variatif. Bandung: PT Rosda Karya. 